\title{
Antioxidant activities and quality characteristics of Yanggeng added with aged black chestnut inner shell
}

\author{
Seok Ryong Lee, Jun Young Lim, Mee Ree Kim* \\ Department of Food and Nutrition, Chungnam National University, Daejeon 34134, Korea
}

숙성 흑율피 첨가 양갱의 품질 특성 및 항산화성

\author{
이석룡·임준영 · 김미리* \\ 충남대학교 식품영양학과
}

\begin{abstract}
This study was performed to evaluate the quality characteristics and the antioxidant activities of yanggeng added with the aged black chestnut inner shells (ACI). The levels of ACI addition to Yanggeng were $0 \%, 1 \%, 3 \%$, or $5 \%$. The moisture content and the reducing sugar contents of Yanggeng increased with the amount of ACI. The pH of Yanggeng with ACI decreased with the amount of ACI, but the acidity increased. Depending on the amount of ACI added, the lightness (L) and yellowness (b) values of Yanggeng with ACI decreased in the Hunter color system, and the redness (a) value increased. Textural properties by TPA showed that hardness, springiness and chewiness decreased as increase in the amount of ACI added. Total phenol content in the Yanggeng added with ACI increased with the amount of ACI added. Increasing amount of ACI addition enhanced antioxidant activities of Yanggeng, as evidenced by DPPH radical scavenging activity and hydroxyl radical scavenging activity assays. In the preference test, Yanggeng added with $3 \%$ ACI showed the highest overall preference and texture. Based on these results, when $3 \%$ ACI was added to Yanggeng the quality characteristics, antioxidant property and sensory properties were excellent.
\end{abstract}

Key words : aged black chestnut inner shell, Yanggeng, quality characteristics, antioxidant activity

\section{서 론}

양갱은 삶은 팥을 체에 거른 후 설탕과 한천 등을 넣고 틀에 넣어 굳힌 후식류의 일종으로 조선시대에는 한천 대신 녹말을 넣고 되직하게 끓여 식혀서 만들었다(1). 양갱은 달고 부드러워 어린이, 노약자의 기호식품으로 선호도가 높은 편이다. 양갱의 종류로는 주 재료에 따라 팥양갱, 밤양 갱, 녹두양갱, 완두양갱, 고구마양갱, 호박양갱 등이 있다. 또한, 최근 건강에 대한 관심이 증가하면서 건강에 도움을 주는 여러 가지 부재료를 첨가한 딸기양갱, 녹차양갱, 매실

*Corresponding author. E-mail : mrkim@cnu.ac.kr Phone : 82-42-821-6837, Fax : 82-42-821-8887

Received 8 February 2017; Revised 18 April 2017; Accepted 20 April 2017.

Copyright (c) The Korean Society of Food Preservation. All rights reserved.
양갱 등 종류가 다양하다. 양갱에 관한 연구로는 황기가루 첨가량에 따른 양갱(2), 마늘과 칼슘을 첨가한 기능성 양갱 (3), 냉동 송이 첨가에 따른 송이 양갱의 품질(4), 늙은 호박 의 혼합비율을 달리하여 제조한 호박양갱(5), 입도별 홍화 씨 분말 첨가에 따른 양갱의 품질(6), 강낭콩 앙금 비율에 따른 양갱의 특성(7), 숙지황 농축액 첨가 양갱(1), 발효숙성 마늘 페이스트 첨가량에 따른 양갱(8) 등이 있다.

밤의 속껍질인 율피는 식품가공부산물로 대부분이 폐기 되므로 식품으로서의 이용가치가 낮지만, 율피 내의 탄닌 물질은 항산화능이 뛰어나고, 율피와 함께 소량 제거되는 과육의 전분으로서 이용가치는 향상되고 있다(9). 특히 율 피의 폴리페놀성분은 갈릭산, 카테킨 등으로 항산화, 항염 증, 면역증강, 미백, 주름개선 등의 효능이 뛰어나다(10). 또한 율피 추출물 및 분획물이 활성화된 비만세포에서 분비 되는 다양한 사이토카인의 생성량을 억제함을 확인하였다 (11). 그러나 율피는 특유의 씁쓸한 맛으로 인해 소비자에게 
다소 거부감이 있어 식품가공에 다양하게 이용되지 못하는 실정이며, 양갱에 접목 한 연구는 없는 실정이다. 또한, 율피 를 숙성하였을 때 항산화능이 증가되고 떫은 맛이 감소되었 으므로 본 연구에서는 항산화능이 우수한 숙성 흑율피를 양갱에 첨가하여 만든 후 품질특성 및 항산화성을 분석하였 다(12).

\section{재료 및 방법}

\section{실험재료}

본 실험에 사용된 율피는 대전 농수산물시장(오정동)에 서 구입하여 $-70^{\circ} \mathrm{C}$ 에 냉동 보관하여 사용하였다. 온도 $50^{\circ} \mathrm{C}$, 습도 $95 \%$ 의 항온항습기(TH-150TP, Hanyang Science, Seoul, Korea)에서 15 일간 대전 생 막걸리(알코올 함량 $7 \%$, (주)대전주조)로 숙성하여 흑율피를 제조하였고, 이것을 건 조한 후 분말 형태로 만들어 사용하였다.

팥앙금(Daedoofood, Jeonju, Korea), 한천(Msagar, Yangsan, Korea), 프락토올리고당과 설탕(CJ CheilJedang, Seoul, Korea)을 사용하였다.

\section{양갱 제조 방법}

숙성 흑율피 양갱의 재료배합은 Table 1 과 같으며, 제조 과정은 Fig. 1 과 같이 제조하였다. 양갱에 첨가하는 숙성 흑율피 가루의 양은 최대한 많이 함유하도록 예비실험결과 를 통해 수 회 제조하여 관능평가한 결과를 바탕으로 적절 하다고 판단되는 양을 선정하였다.

\begin{tabular}{|c|}
\hline Water, Ager \\
\hline$\downarrow$ Stirring, boiling for $15 \mathrm{~min}$ \\
\hline $\begin{array}{l}\text { Adding cooked red bean }(50 \%) \\
\text { and aged black chestnut inner shell }\end{array}$ \\
\hline$\downarrow$ Stirring, boiling for $1 \mathrm{~min}$ \\
\hline Adding fructo-saccharides and sugar \\
\hline$\downarrow$ Stirring, boiling for $10 \mathrm{~min}$ \\
\hline Molding \\
\hline$\downarrow$ Cooling for $24 \mathrm{~h}$ \\
\hline Aged chestnut inner shell yanggeng \\
\hline
\end{tabular}

Fig. 1. Scheme of aged black chestnut inner shell Yanggeng preparation.

\section{수분함량}

양갱의 수분함량을 측정하기 위해 각 시료 약 $1.5 \mathrm{~g}$ 을 정확히 취하여 적외선 수분측정기(ISCO, US/Retriever 500, Sartorius, Lincoln, NE, USA)를 사용하여 측정하고, 측정
시료는 3회 반복 측정하여 그 평균값을 구하였다.

Table 1. Recipe of Yanggeng added with different amount of aged black chestnut inner shell powder

\begin{tabular}{ccccc} 
& & & & (unit: g) \\
\hline Ingredients & Control & ACl $^{1)} 1 \%$ & ACI 3\% & ACI 5\% \\
\hline Red bean & 200 & 196 & 188 & 180 \\
Fructo-oligosaccharide & 20 & 20 & 20 & 20 \\
Sugar & 26 & 26 & 26 & 26 \\
Agar & 4 & 4 & 4 & 4 \\
Water & 150 & 150 & 150 & 150 \\
ACI & 0 & 4 & 12 & 20 \\
\hline Total weight & 400 & 400 & 400 & 400 \\
\hline
\end{tabular}

${ }^{1)} \mathrm{ACI}$, aged black chestnut inner shell. Percentage means the weight \% of total flour weight.

\section{가용성 고형물 함량 및 환원당}

시료 $5 \mathrm{~g}$ 을 $45 \mathrm{~mL}$ 의 증류수와 함께 넣고 균질화 한 뒤 $3,000 \mathrm{rpm}$ 에서 15 분간 원심분리한 후 상등액을 취하여 당도 계(N-1E Brix 0-32\%, Atago, Tokyo, Japan)를 이용하여 측정 하였다. 환원당은 당도 측정의 시료와 같은 시료로 dinitrosalicylic acid(DNS)에 의한 비색법으로 분광광도계 (UV-1800 240 V, Beckman, Fullerton, CA, USA)를 사용하 여 $550 \mathrm{~nm}$ 에서 흡광도를 측정하였다. 표준곡선은 glucose (Duksan pharmaceutical Co., Asan, Korea)를 농도별로 반응 시켜 작성하였다.

\section{$\mathrm{pH}$ 및 산도}

시료 $4 \mathrm{~g}$ 을 $36 \mathrm{~mL}$ 의 증류수와 함께 넣고 $\mathrm{Bag}$ Mixer (Model 400, Interscience, Mourjou, France)를 이용하여 균질 화하였다. $3,000 \mathrm{rpm}$ 에서 15 분간 원심분리(Combi-514R, Hanil, Anyang, Korea)한 후 상등액을 취하여 $\mathrm{pH}$ meter(420 Benchtop, Orion Research, Beverly, DC, USA)로 측정하였 다. 산도는 $\mathrm{pH}$ 와 동일한 방법으로 준비하여 상등액 $10 \mathrm{~mL}$ 취하고 $\mathrm{pH}$ 8.3까지 도달하는데 필요한 $0.1 \mathrm{~N} \mathrm{NaOH}$ 양 $(\mathrm{mL})$ 을 citric acid 함량(\%)으로 환산하여 총산 함량을 표시하였 다.

$$
\operatorname{Acidity}(\%)=\frac{\mathrm{mL} \text { of } 0.1 \mathrm{~N} \mathrm{NaOH} \times 0.0064}{\text { Weight of sample }} \times 100
$$

색 도

색도는 색차계(D-1001 DP, Nippon Denshoku Co., Tokyo, Japan)를 사용하여 백색도, 적색도, 황색도를 4회 반복 측정 하여 평균값으로 나타내었다. 시료 $20 \mathrm{~g}$ 씩 갈아 균일하게 섞은 뒤 $10 \mathrm{~g}$ 을 취한 후 페트리디쉬 $(50 \times 12 \mathrm{~mm})$ 에 빈 공간이 생기지 않게 담아 색도를 측정하였다. Standard color value 
는 $\mathrm{L}$ 값 $97.01, \mathrm{a}$ 값 $6.61, \mathrm{~b}$ 값 $-0.91, \Delta \mathrm{E}$ 값 0.04 인 calibration plate를 표준으로 사용하였다.

조직감

양갱의 조직감 특성을 알아보기 위하여 시료는 $1.5 \times$ $1.5 \times 1.5 \mathrm{~cm}$ 크기로 잘라 texture analyser(TA/XT2, Stable Micro System Ltd., Surrey, England)를 사용하여 5회 이상 측정하였다. 지름 $25 \mathrm{~mm}$ 의 plunger를 이용하여 hardness를 측정하였다. 분석조건은 pre test speed $2.0 \mathrm{~mm} / \mathrm{sec}$, test speed $2.0 \mathrm{~mm} / \mathrm{s}$, post test speed $2.0 \mathrm{~mm} / \mathrm{s}$, distance $7.0 \mathrm{~mm}$, return distance $20.0 \mathrm{~mm}$, contact force $5.0 \mathrm{~g}$ 로 하였으며 양갱의 표면이 고르고 편평한 곳을 측정하였다.

\section{총 Total phenol 함량}

총 phenol은 페놀성 물질이 phosphomolybdic acid와 반응 하여 청색을 나타내는 현상을 이용한 Folin-Denis법으로 측정하였다. 동결건조 시킨 시료 $1.5 \mathrm{~g}$ 에 $\mathrm{MeOH}$ 로 $50 \mathrm{~mL}$ mass up 한 후 15 시간 동안 교반하여 $3,000 \mathrm{rpm}$ 으로 $4^{\circ} \mathrm{C}$ 에서 10 분간 원심 분리하여 얻어진 상징 액을 evaporator로 용매 를 휘발하여 추출물만 얻었다. 추출물을 PBS buffer로 녹인 $100 \mathrm{mg} / \mathrm{mL}$ 시료용액에 Folin-Denis 시약과 $\mathrm{Na}_{2} \mathrm{CO}_{3}$ 포화용 액을 넣고 암소에서 30 분 반응시킨 후, 흡광도 $760 \mathrm{~nm}$ 에서 측정하였다. Standard curve는 tannic acid를 여러 농도로 희석하여 반응시켜 사용하였다.

\section{$\mathrm{DPPH}$ 라디칼 소거능}

동결건조 시킨 시료 $1.5 \mathrm{~g}$ 에 $\mathrm{MeOH}$ 로 $50 \mathrm{~mL}$ mass up 한 뒤 15 시간 동안 $150 \mathrm{rpm}$ 으로 교반 후 $3,000 \mathrm{rpm}, 4^{\circ} \mathrm{C}$ 조건으로 10 분간 원심분리하여 얻어진 상징액을 취해 filter paper로 거른 뒤 evaporator로 용매를 휘발하여 추출물만 얻었다. 추출물에 $\mathrm{MeOH}$ 을 $100 \mathrm{mg} / \mathrm{mL}$ 농도가 되도록 첨가 하여 추출물 용액을 제조한 뒤 시료 용액으로 사용하였다. 각각의 희석한 시료용액 $50 \mu \mathrm{L}$ 에 $150 \mu \mathrm{L}$ 의 $1.5 \times 10^{-4} \mathrm{mM}$ DPPH(1,1-diphenyl-2-picryl hydrazyl)용액을 가한 후 30분 간 실온에서 방치한 뒤 엘라이저를 이용하여 $515 \mathrm{~nm}$ 에서 흡광도를 측정하여 radical 소거능(\%)을 다음 식으로 계산 한 후 각 농도별 radical 소거능에 대한 검량선에서 라디칼 소거능이 $50 \%$ 가 되는 농도인 $\mathrm{IC}_{50}$ 값을 구하였다.

$$
\text { Free radical scavenging effect }(\%)=\frac{\mathrm{AbS}_{\mathrm{DPPH}}-\mathrm{Ab \textrm {S } _ { \text { sample } }}}{\mathrm{Abs}_{\mathrm{DPPH}}} \times 100
$$

\section{Hydroxyl radical 소거능}

동결건조 시킨 시료 $1.5 \mathrm{~g}$ 을 $\mathrm{MeOH}$ 로 $50 \mathrm{~mL}$ 까지 mass up 한 후 $150 \mathrm{rpm}$ 에서 15 시간 동안 잘 교반하여 $3,000 \mathrm{rpm}$, $4{ }^{\circ} \mathrm{C}$ 조건으로 10 분간 원심분리하여 얻어진 상징액을 취해 filter paper로 거른 뒤, evaporator로 용매를 휘발하여 추출물
을 얻었다. 추출물을 $100 \mathrm{mg} / \mathrm{mL}$ 농도가 되도록 PBS buffer 로 녹인 뒤 사용하였다. 각각의 시료를 희석한 뒤, 시료용액 $0.15 \mathrm{~mL}$ 에 PBS buffer $0.35 \mathrm{~mL}, 3 \mathrm{mM}$ deoxyribose, 0.1 $\mathrm{mM}$ ascorbic acid, $0.1 \mathrm{mM}$ EDTA, $0.1 \mathrm{mM} \mathrm{FeCl}, 1 \mathrm{mM}$ $\mathrm{H}_{2} \mathrm{O}_{2}$ 용액을 각각 $0.1 \mathrm{~mL}$ 씩 순서대로 넣어 잘 교반한 후 $37^{\circ} \mathrm{C}$ 에서 1 시간 반응시켰다. 반응 후 $2 \% \mathrm{TCA}$ 용액 $1 \mathrm{~mL}$ 과 $1 \% \mathrm{TBA}$ 용액 $1 \mathrm{~mL}$ 을 넣고 잘 섞어 $100^{\circ} \mathrm{C}$ 에서 20 분간 반응 시킨 후 냉각하여 원심분리한 뒤 상징액을 취하여 분광광도 계를 이용하여 $532 \mathrm{~nm}$ 에서 흡광도를 측정하였으며 radical 소거능(\%)을 다음의 식으로 계산한 후 각 농도별 radical 소거능에 대한 검량선에서 라디칼 소거능이 $50 \%$ 가 되는 농도인 $\mathrm{IC}_{50}$ 값을 구하였다.

Free radical scavenging effect $(\%)=\frac{\mathrm{Abs}_{\text {blank }}-\mathrm{Abs}_{\text {sample }}}{\mathrm{Abs} \text { blank }} \times 100$

관능검사

숙성 흑율피 첨가 양갱의 관능검사는 기호도와 강도 특 성으로 나누어 평가하였다. 강도특성은 외관(glossiness, color), 냄새(odor of $\mathrm{ACl}$ ), 맛(sweetness, flavor of $\mathrm{ACI}$ ), 질감 (springness, hardness, adhesiveness, after taste)에 대하여 관 능검사에 익숙한 충남대학교 식품영양학과 대학생과 대학 원생 10명을 대상으로 7점 척도법(1점, 매우 약함; 7점, 매우 강함)을 사용하여 검사하였다. 기호도 검사는 외관, 향, 맛, 조직감, 구입의사, 전반적인 기호도에 대하여 7점 척도(1점, 매우 싫다; 7점, 매우 좋다)를 사용하여 대학생 30명을 대상 으로 실시하였다. 시료는 세 자리 난수를 표기한 일회용 접시에 담아 제시하였고, 다음 시료 평가에 미치는 영향을 줄이기 위해 따뜻한 물과 함께 제공하였다.

\section{통계처리}

실험결과는 SPSS 21.0(Statistical Package for Social Science. SPSS Inc., Chicago IL, USA) software package 프로 그램 중에서 분산분석(ANOVA)을 실시하여 유의성이 있 는 경우에 Duncan의 다중범위검정(Duncan's multiple range test)으로 시료간의 유의차를 검정하였다.

\section{결과 및 고찰}

\section{수분함량}

숙성 흑율피 첨가량에 따른 양갱의 수분함량 측정결과는 Table 2와 같다. 수분함량은 숙성 흑율피를 첨가하지 않은 대조군의 수분함량은 $26.97 \%$, 숙성 흑율피 $1 \%$ 첨가 양갱은 $27.46 \%, 3 \%$ 숙성 흑율피 첨가 양갱은 $31.12 \%$, 숙성 흑율피 $5 \%$ 첨가 양갱은 $32.91 \%$ 로 숙성 흑율피의 첨가량이 증가할 수록 수분함량이 유의적으로 증가하였다( $\mathrm{p}<0.05)$. 율피 분 
말을 첨가한 쿠키(9)에 사용된 율피 분말의 수분함량은 $4.35 \%$ 로 낮지만 율피분말의 이화학적 특성 연구(13)에 따 르면 율피분말의 수분결합능력이 높다고 보고하였다. 이와 같은 결과로부터 숙성 흑율피가 수분을 보유하는 효과가 있는 것으로 생각되었다. 녹차가루 첨가가 양갱의 품질에 미치는 영향에 따른 결과(14)에서는 녹차가루를 $8 \%$ 첨가한 양갱의 수분함량이 $49.15 \%$ 로 나타났고, 녹차가루의 첨가 량이 증가할수록 수분함량도 증가하는 경향을 보였다.

Table 2. Moisture content of Yanggeng added with different amount of aged black chestnut inner shell powder

\begin{tabular}{|c|c|c|c|c|}
\hline \multirow{2}{*}{ Moisture (\%) } & Control & $\mathrm{ACl}^{1)} 1 \%$ & ACI $3 \%$ & ACI $5 \%$ \\
\hline & $26.97 \pm 3.31^{2 b 3)}$ & $27.46 \pm 1.77^{b}$ & $31.12 \pm 1.36^{\mathrm{a}}$ & $32.91 \pm 1.65^{\mathrm{a}}$ \\
\hline
\end{tabular}
significantly different by Duncan's multiple range test at $\mathrm{p}<0.05$.

\section{당도 및 환원당}

숙성 흑율피 첨가량에 따른 양갱의 당도 및 환원당 측정 결과는 Table 3 과 같다. 당도는 숙성 흑율피를 첨가하지 않은 대조군은 $48.7^{\circ} \mathrm{Brix}$, 숙성 흑율피 $1 \%$ 첨가 양갱은 $46.7^{\circ} \mathrm{Brix}$, 숙성 흑율피 $3 \%$ 첨가 양갱은 $44.7^{\circ} \mathrm{Brix}$, 숙성 흑율피 $5 \%$ 첨가 양갱은 $42.7^{\circ} \mathrm{Brix}$ 를 나타내어 숙성 흑율피 첨가량이 증가할수록 당도는 유의적으로 낮아졌다 $(\mathrm{p}<0.05)$. 이와 같은 결과는, $\operatorname{Han}$ 과 $\operatorname{Kim}(15)$ 의 연구에서 생강가루 첨가했을 때 당도가 감소했다는 결과와 유사한 경향을 나타 내었다. 반면에 블루베리 분말 첨가 양갱의 연구(16)에서는 부재료의 첨가량이 증가할수록 당도가 증가하는 경향을 보였다고 보고하여 본 실험의 결과와 차이를 보였다.

숙성 흑율피를 첨가하지 않은 대조군의 환원당은 $1.27 \%$, 숙성 흑율피 $1 \%$ 첨가 양갱은 $1.26 \%$ 로 대조군과 유의적인 차이는 없었으나, 숙성 흑율피 $3 \%$ 첨가 양갱은 $1.24 \%$, 숙성 흑율피 $5 \%$ 첨가 양갱은 $1.23 \%$ 로 대조군에 비하여 유의적 으로 감소하였다( $\mathrm{p}<0.05)$.

Table 3. Soluble solid content and reducing sugar of Yanggeng added with different amount of aged black chestnut inner shell powder

\begin{tabular}{|c|c|c|c|c|}
\hline & Control & $\mathrm{ACI}^{1)} 1 \%$ & ACI $3 \%$ & ACI $5 \%$ \\
\hline $\begin{array}{l}\text { Soluble solid content } \\
\text { ( }{ }^{\mathrm{B} B \mathrm{Bix})}\end{array}$ & $\left.48.7 \pm 0.1^{2 \mathrm{a} a}\right)$ & $46.7 \pm 0.1^{b}$ & $44.7 \pm 0.1^{\mathrm{c}}$ & $42.7 \pm 0.1^{\mathrm{d}}$ \\
\hline Reducing sugar (\%) & $1.27 \pm 0.01^{\mathrm{a}}$ & $1.26 \pm 0.02^{\mathrm{ab}}$ & $1.24 \pm 0.01^{b}$ & $1.23 \pm 0.01^{b}$ \\
\hline
\end{tabular}

\section{$\mathrm{pH}$ 및 산도}

숙성 흑율피 첨가량에 따른 양갱의 $\mathrm{pH}$ 및 산도의 측정 결과는 Table 4와 같다. 숙성 흑율피를 첨가하지 않은 대조 군의 $\mathrm{pH}$ 는 6.44 , 숙성 흑율피 $1 \%$ 첨가 양갱은 6.14 , 숙성 흑율피 $3 \%$ 첨가 양갱은 5.76 , 숙성 흑율피 $5 \%$ 첨가 양갱은 5.54 로 숙성 흑율피의 첨가량이 증가할수록 $\mathrm{pH}$ 는 유의적으 로 낮아졌다 $(\mathrm{p}<0.05)$.

산도는 숙성 흑율피를 첨가하지 않은 대조군은 $0.01 \%$, 숙성 흑율피 $1 \%$ 첨가 양갱은 $0.02 \%$, 숙성 흑율피 $3 \%$ 첨가 양갱은 $0.05 \%$, 숙성 흑율피 $5 \%$ 첨가 양갱은 $0.09 \%$ 로 숙성 흑율피의 첨가량이 증가할수록 유의적으로 높아졌다 $(\mathrm{p}<0.05)$.

숙성 흑율피의 품질 특성 연구(12)에서 흑율피의 숙성일 차가 증가함에 따라 $\mathrm{pH}$ 가 감소하고 산도가 증가되는 것으 로 보고하였다. 본 실험에서는 15 일 숙성한 흑율피를 사용 하였으므로 숙성 흑율피의 함량이 증가할수록 $\mathrm{pH}$ 는 감소 하고 산도는 증가한 것으로 사료된다.

Table 4. $\mathrm{pH}$ and acid value of Yanggeng added with different amount of aged black chestnut inner shell powder

\begin{tabular}{ccccc}
\hline & Control & $\mathrm{ACI}^{1)} 1 \%$ & $\mathrm{ACI} 3 \%$ & $\mathrm{ACI} 5 \%$ \\
\hline $\mathrm{pH}$ & $6.44 \pm 0.08^{2) \mathrm{a} 3)}$ & $6.14 \pm 0.03^{\mathrm{b}}$ & $5.76 \pm 0.01^{\mathrm{c}}$ & $5.54 \pm 0.01^{\mathrm{d}}$ \\
Acid value (\%) & $0.01 \pm 0.00^{\mathrm{d}}$ & $0.02 \pm 0.00^{\mathrm{c}}$ & $0.05 \pm 0.00^{\mathrm{b}}$ & $0.09 \pm 0.00^{\mathrm{a}}$ \\
\hline
\end{tabular}

${ }^{11} \mathrm{ACl}$, aged black chestnut inner shell. Percentage means the weight \% of total flour weight.

${ }^{2)}$ All values are Mean $\pm \mathrm{SD}(\mathrm{n}=3)$.

3)a-d Different superscripts in the same row (aged black chestnut inner shell) are significantly different by Duncan's multiple range test at $\mathrm{p}<0.05$.

색 도

숙성 흑율피 첨가량에 따른 양갱의 색도 측정 결과는 Table 5와 같다. 명도(lightness)를 나타내는 L 값은 숙성 흑율피를 첨가하지 않은 대조군은 15.49 이었고, 숙성 흑율 피 $1 \%$ 첨가 양갱은 13.54 , 숙성 흑율피 $3 \%$ 첨가 양갱은 11.41 , 숙성 흑율 피 $5 \%$ 첨가 양갱은 10.38 로 숙성 흑 율피 첨가량이 증가함에 따라 유의적으로 감소하였다 $(\mathrm{p}<0.05)$ 이는 숙성 흑율피 가루가 어두운 진한 갈색을 띄기 때문인 것으로 보이며, 숙지황 농축액을 첨가한 양갱의 품질 특성 연구(5)에서 숙지황 농축액 첨가군의 명도가 유의적으로 낮았다고 보고한 결과와 유사하였다. 적색도를 나타내는 $\mathrm{a}$ 값은 숙성 흑율피를 첨가하지 않은 대조군은 7.61 이었고, 숙성 흑율피 $1 \%$ 첨가 양갱은 7.86 , 숙성 흑율피 $3 \%$ 첨가 양갱은 7.87로 대조군과 유의적인 차이가 없었으나, 숙성 흑율피 $5 \%$ 첨가 양갱은 8.86 으로 대조군에 비해 유의적으 로 증가하였다 $(\mathrm{p}<0.05)$. 블루베리 분말을 첨가한 양갱의 품 질 특성 연구(16)에서 블루베리 분말의 첨가비율이 증가할 수록 적색도가 증가하였지만 유의적인 차이는 보이지 않았 다고 보고하여 본 실험과 유사한 결과를 보였다. 황색도를 
나타내는 b 값은 숙성 흑율피를 첨가하지 않은 대조군은 3.65 이었고, 숙성 흑율피 $1 \%$ 첨가 양갱은 3.59 로, 대조군과 유의적인 차이가 없었으나, 숙성 흑율피 $3 \%$ 첨가 양갱은 2.79 , 숙성 흑율피 $5 \%$ 첨가 양갱은 1.61 으로 숙성 흑 율피 첨가량이 증가함에 따라 유의적으로 감소하였다 $(\mathrm{p}<0.05)$. 파프리카분말 첨가 양갱의 연구(19)에서는 파프리카분말 의 첨가량이 증가할수록 황색도가 증가하는 경향을 나타냈 다고 보고하여 첨가되는 부재료에 따라 색도 특성이 각각 다르게 나타나는 것을 알 수 있었다.

Table 5. Color value of Yanggeng added with different amount of aged black chestnut inner shell powder

\begin{tabular}{ccccc}
\hline & Control & $\mathrm{ACl}^{1)} 1 \%$ & ACI 3\% & ACI 5\% \\
\hline Lightness (L) & $15.49 \pm 0.08^{2) \mathrm{a} 3)}$ & $13.54 \pm 0.04^{\mathrm{b}}$ & $11.41 \pm 0.12^{\mathrm{c}}$ & $10.38 \pm 0.11^{\mathrm{d}}$ \\
Redness (a) & $7.61 \pm 0.33^{\mathrm{b}}$ & $7.86 \pm 0.16^{\mathrm{b}}$ & $7.87 \pm 0.44^{\mathrm{b}}$ & $8.86 \pm 0.29^{\mathrm{a}}$ \\
Yellowness (b) & $3.65 \pm 0.05^{\mathrm{a}}$ & $3.59 \pm 0.09^{\mathrm{a}}$ & $2.79 \pm 0.21^{\mathrm{b}}$ & $1.61 \pm 0.11^{\mathrm{c}}$ \\
\hline
\end{tabular}

${ }^{1)} \mathrm{ACI}$, aged black chestnut inner shell. Percentage means the weight $\%$ of total flour weight.

${ }^{2)}$ All values are Mean $\pm \mathrm{SD}(\mathrm{n}=3)$.

3)-dDifferent superscripts in the same row (aged black chestnut inner shell) are significantly different by Duncan's multiple range test at $p<0.05$.

\section{조직감}

숙성 흑율피 첨가량에 따른 양갱의 조직감을 texture analyzer로 측정한 결과는 Table 6과 같다. 경도의 경우, 숙성 흑율피를 첨가하지 않은 대조군은 $4,288 \mathrm{~g}$, 숙성 흑율 피 $1 \%$ 첨가 양갱은 $3,634 \mathrm{~g}$, 숙성 흑율피 $3 \%$ 첨가 양갱은 $3,337 \mathrm{~g}$, 숙성 흑율피 $5 \%$ 첨가 양갱은 $2,997 \mathrm{~g}$ 으로 흑율피 첨가량이 증가함에 따라 유의적으로 감소하였다 $(\mathrm{p}<0.05)$. 이와 같은 결과는 숙성 흑 율피 첨가량이 증가함에 따라 수분함량이 증가(Table 1)한데 기인한 것으로 생각된다. 또 한, 녹차가루 첨가양갱(14), 생강가루 첨가 양갱(15)의 연구 에서도 부재료의 첨가량이 증가할수록 경도가 감소했다고 하여 본 실험과 유사한 결과를 나타내었다. 반면에, 더덕 첨가 양갱(20), 파프리카 분말 첨가 양갱(19), 흑임자 분말 첨가 양갱(21)의 연구에서는 부재료 첨가 비율이 증가할수 록 양갱의 경도가 증가한다고 보고하여 본 실험과 차이를 보였다. 이것은 더덕, 파프리카, 흑임자 등에 함유된 펙틴성 분들이 양갱의 조직감을 더욱 강화시킨 것으로 추정된다. 한편, 탄력성은 숙성 흑율피를 첨가하지 않은 대조군은 0.97 , 숙성 흑율피 $1 \%$ 첨가 양갱은 0.94 , 숙성 흑율피 $3 \%$ 첨가 양갱은 0.89 , 숙성 흑율피 $5 \%$ 첨가 양갱은 0.83 로 각각 유의적 차이를 나타내었다( $\mathrm{p}<0.05)$. 이는 더덕을 첨가한 양 갱 실험(21)에서 더덕의 첨가량이 증가할수록 탄력성이 감 소하는 경향을 보인 것과 유사한 결과를 나타내었다. 응집 성은 숙성 흑율피를 첨가하지 않은 대조군은 0.56 , 숙성 흑율피 $1 \%$ 첨가 양갱은 0.51 , 숙성 흑율피 $3 \%$ 첨가 양갱은 0.50 , 숙성 흑율피 $5 \%$ 첨가 양갱은 0.43 으로, $1 \%$ 숙성 흑율
피 첨가 양갱과 $3 \%$ 숙성 흑율피 첨가 양갱은 유의적인 차이를 나타내지 않았지만, 첨가량이 증가함에 따라 응집 성은 감소하였다. 이는 홍화씨 분말을 첨가한 양갱(6)의 경우에서 응집성의 뚜렷한 차이가 나타나지 않았다는 결과 와는 상이하였다. 검성은 숙성 흑율피를 첨가하지 않은 대 조군은 $4,287,1 \%$ 숙성 흑율피 첨가 양갱은 $3,634,3 \%$ 숙성 흑율피 첨가 양갱은 $3,357,5 \%$ 숙성 흑율피 첨가 양갱은 $2,996$ 로 유의적으로 감소하였다( $\mathrm{p}<0.05)$. 이는 생강가루를 첨가하여 제조한 양갱의 연구(15)에서 생강가루의 첨가량 이 증가할수록 검성이 감소하였다는 결과와 유사하였다. 씹힘성은 숙성 흑율피를 첨가하지 않은 대조군은 4,283 , $1 \%$ 첨가군은 $3,631,3 \%$ 첨가군은 $3,334,5 \%$ 첨가군은 2,994 으로 숙성 흑율피 첨가량이 증가함에 따라 유의적으로 감소 하였다 $(\mathrm{p}<0.05)$. 이 결과는 홍삼을 첨가하여 제조한 양갱 (17)의 조직감 측정실험에서 홍삼의 첨가량이 증가할수록 씹힘성이 증가한다는 결과와 반대로 나타났다. 이는 첨가 되는 부재료에 따라 조직감 특성이 나르게 나타난다는 것을 보여준다고 할 수 있다. 회복 탄력성(resilience)은 숙성 흑율 피를 첨가하지 않은 대조군은 0.028 , 숙성 흑율피 $1 \%$ 첨가 양갱은 0.024 , 숙성 흑율피 $3 \%$ 첨가 양갱은 0.018 , 숙성 흑율피 $5 \%$ 첨가 양갱은 0.017 로 각각 유의적인 차이를 나타 냈지만, $3 \%$ 숙성 흑율피 양갱과 $5 \%$ 숙성 흑율피 양갱은 서로 유의적 차이를 나타내지 않았다.

Table 6. Texture of Yanggeng added with different amount of aged black chestnut inner shell powder

\begin{tabular}{ccccc}
\hline & Control & ACI $^{1)} 1 \%$ & ACI 3\% & ACI 5\% \\
\hline Hardness (g) & $4,288 \pm 278^{2) 33)}$ & $3,834 \pm 241^{\mathrm{b}}$ & $3,537 \pm 168^{\mathrm{bc}}$ & $2,997 \pm 340^{\mathrm{c}}$ \\
Springness & $0.974 \pm 0.020^{\mathrm{a}}$ & $0.937 \pm 0.009^{\mathrm{b}}$ & $0.885 \pm 0.021^{\mathrm{c}}$ & $0.827 \pm 0.021^{\mathrm{d}}$ \\
Cohesiveness & $0.563 \pm 0.025^{\mathrm{a}}$ & $0.510 \pm 0.020^{\mathrm{b}}$ & $0.498 \pm 0.011^{\mathrm{b}}$ & $0.430 \pm 0.011^{\mathrm{c}}$ \\
Gumminess & $4,287 \pm 329^{\mathrm{a}}$ & $3,634 \pm 341^{\mathrm{b}}$ & $3,357 \pm 242^{\mathrm{bc}}$ & $2,996 \pm 340^{\mathrm{c}}$ \\
Chewiness & $4,283 \pm 330^{\mathrm{a}}$ & $3,631 \pm 341^{\mathrm{b}}$ & $3,334 \pm 217^{\mathrm{bc}}$ & $2,994 \pm 339^{\mathrm{c}}$ \\
Resilience & $0.028 \pm 0.001^{\mathrm{a}}$ & $0.024 \pm 0.003^{\mathrm{b}}$ & $0.018 \pm 0.001^{\mathrm{c}}$ & $0.017 \pm 0.001^{\mathrm{c}}$ \\
\hline
\end{tabular}

${ }^{1)} \mathrm{ACI}$, aged black chestnut inner shell. Percentage means the weight $\%$ of total flour weight.

${ }^{2)}$ All values are Mean $\pm \mathrm{SD}(\mathrm{n}=3)$.

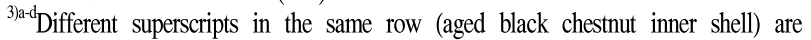
significantly different by Duncan's multiple range test at $p<0.05$.

\section{총 phenol 함량}

숙성 흑율피 첨가에 따른 양갱의 총 phenol 함량 측정 결과는 Fig. 2 와 같다. 숙성 흑율피를 첨가하지 않은 대조군 의 총 phenol 양은 $0.079 \mathrm{mg} / \mathrm{mL}, 1 \%$ 숙성 흑율피 첨가 양갱 은 $0.138 \mathrm{mg} / \mathrm{mL}, 3 \%$ 숙성 흑율피 첨가 양갱은 $0.303 \mathrm{mg} / \mathrm{mL}$, $5 \%$ 숙성 흑율피 첨가 양갱은 $0.305 \mathrm{mg} / \mathrm{mL}$ 로 숙성 흑율피의 첨가량이 증가함에 따라 총 phenol 양이 증가함을 보였다. 숙성 흑율피를 첨가하지 않은 대조군과 $5 \%$ 숙성 흑율피 첨가 양갱은 유의적인 차이를 나타냈다(p<0.05). 이는 율피 
의 아세톤 추출물에서 총 페놀함량에 비례하여 항산화성이 우수하다고 연구(22)와 유사한 결과를 나타내었다. 페놀성 화합물들은 분자 내에 phenolic hydroxyl기를 가지고 있는 방향족 화합물로 산화-환원반응에서 기질로 작용하며 플라 보노이드와 탄닌이 주된 성분이다. 율피에 함유되어 있는 폴리페놀류에는 ellagic acid, naringenin, gallic acid, flavanol 등이 있으며 이들이 항산화 활성에 관여한다고 보고되었 다. 그러므로 숙성 흑율피를 첨가하지 않은 양갱보다 숙성 흑율피 양갱에서 항산화 효능을 기대할 수 있을 것으로 기대된다.

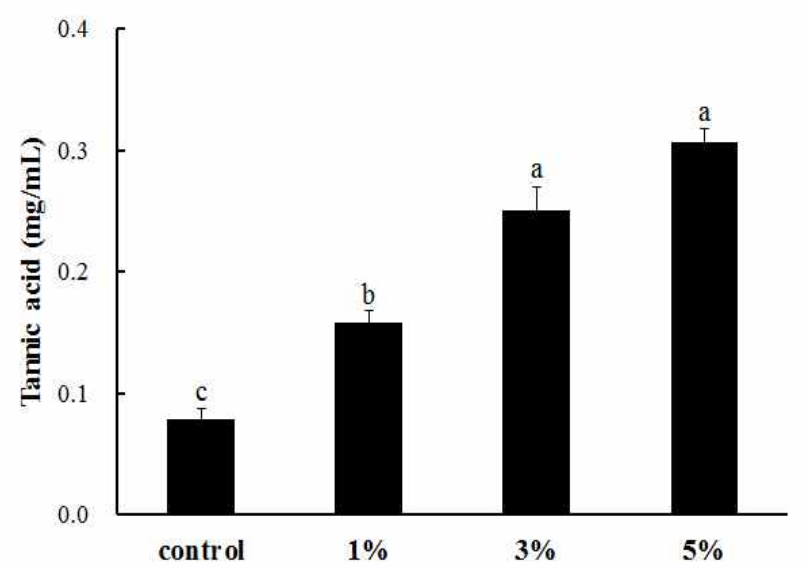

Fig. 2. Total phenol contents of Yanggeng added with different amount of aged black chestnut inner shell powder.

${ }^{\text {acc }}$ Different superscripts in the bars are significantly different by Duncan's multiple range test at $\mathrm{p}<0.05$.

\section{$\mathrm{DPPH}$ 라디칼 소거능}

숙성 흑율피 첨가에 따른 양갱의 DPPH radical 소거능 측정 결과 $\mathrm{IC}_{50}$ 값은 $\mathrm{Fig} .3$ 와 같다. 숙성 흑율피를 첨가하지 않은 대조군의 $\mathrm{IC}_{50}$ 값은 $231.9 \mathrm{mg} / \mathrm{mL}$, 숙성 흑율피 $1 \%$ 첨가군은 $98.4 \mathrm{mg} / \mathrm{mL}$, 숙성 흑율피 $3 \%$ 첨가군은 65.4 $\mathrm{mg} / \mathrm{mL}$, 숙성 흑율피 $5 \%$ 첨가군은 $56.4 \mathrm{mg} / \mathrm{mL}$ 로 숙성 흑율 피의 첨가량이 증가할수록 $\mathrm{IC}_{50}$ 값이 낮아지는 경향을 나타 내었다. 이는 DPPH radical 소거능이 높아지는 것으로, 율피 에 함유되어 있는 총 페놀성 물질의 첨가량의 증가에 따른 결과라고 보여진다. 아로니아즙 첨가 양갱(18)의 항산화 활성 연구에서도 아로니아즙의 첨가량이 증가할수록 DPPH radical 소거능이 높아지는 결과를 보였다. 따라서, 숙성 흑율피 첨가 함량이 증가할수록 율피를 첨가하지 않은 컨트롤 양갱보다 좋은 항산화 효과를 볼 수 있을 것으로 예상된다.

\section{Hydroxyl radical 소거능}

숙성 흑율피 첨가에 따른 양갱의 hydroxyl radical 소거능 을 측정한 결과 $\mathrm{IC}_{50}$ 값은 Fig. 4 와 같다. 숙성 흑율피를 첨가하지 않은 대조군의 $\mathrm{IC}_{50}$ 값은 $6.79 \mathrm{mg} / \mathrm{mL}$, 숙성 흑율피

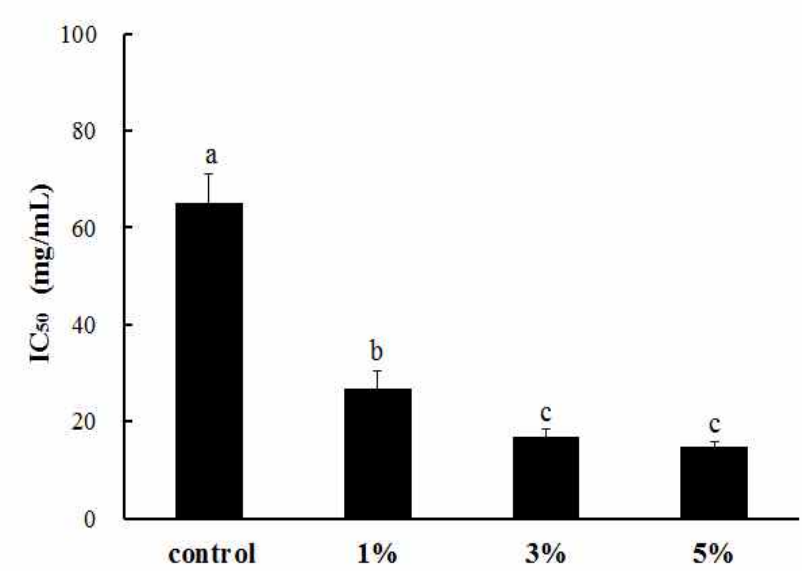

Fig. 3. DPPH radical scavenging activity of Yanggeng added with different amount of aged black chestnut inner shell powder.

${ }^{a-c}$ Different superscripts in the bars are significantly different by Duncan's multiple range test at $\mathrm{p}<0.05$.

$1 \%$ 첨가군의 $\mathrm{IC}_{50}$ 값은 $4.60 \mathrm{mg} / \mathrm{mL}$, 숙성 흑율피 $3 \%$ 첨가군 의 $\mathrm{IC}_{50}$ 값은 $3.76 \mathrm{mg} / \mathrm{mL}$, 숙성 흑율피 $5 \%$ 첨가군의 $\mathrm{IC}_{50}$ 값은 $2.61 \mathrm{mg} / \mathrm{mL}$ 로 숙성 흑율피의 첨가량이 증가함에 따라 $\mathrm{IC}_{50}$ 값이 점점 감소하였다. 숙성 흑율피를 첨가할수록 대조 군에 비해 $\mathrm{IC}_{50}$ 값이 낮아진다는 것은 Hydroxyl radical 소거 능이 높아지는 것으로, 숙성 흑율피 첨가 함량이 증가할수 록 숙성 흑율피를 첨가하지 않은 대조군보다 더 좋은 항산 화 효과를 볼 수 있을 것으로 예상된다. Oh 등(5)의 연구에 서도 숙지황 농축액의 첨가량이 증가할수록 hydroxyl radical 소거능이 증가한다고 보고하였다. 이 결과는 높은 총 페놀성물질의 함량에서 기인한 결과라고 보여진다.

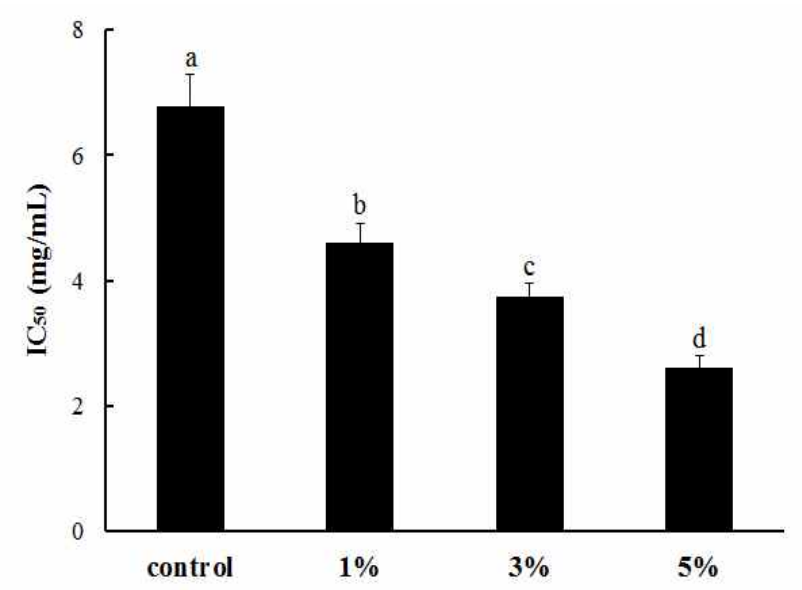

Fig. 4. Hydroxyl radical oxidation activity of Yanggeng added with different amount of aged black chestnut inner shell powder.

${ }^{a-d}$ Different superscripts in the bars are significantly different by Duncan's multiple range test at $p<0.05$.

\section{기호도 특성}

숙성 흑율피 첨가에 따른 양갱의 기호도 특성 결과는 Table 7 과 같다. 외관은 숙성 흑율피 $1 \%$ 첨가 양갱과 숙성 
흑율피 $3 \%$ 첨가 양갱이 4.9 점으로 가장 높은 점수를 받았 고, 냄새, 맛, 조직감에서는 $3 \%$ 숙성 흑율피 첨가 양갱이 각각 4.9점, 5.1점, 4.9점으로 가장 높은 점수를 받았다. 전체 적인 기호도는 $3 \%$ 숙성 흑율피 첨가 양갱이 5.2점으로 가장 높았으며, 숙성 흑율피를 가장 많이 넣은 5\% 숙성 흑율피 첨가 양갱에서 가장 낮은 점수를 받았다.

Table 7. Preference test of Yanggeng added with different amount of aged black chestnut inner shell powder

\begin{tabular}{ccccc}
\hline & Control & $\mathrm{ACI}^{1)} 1 \%$ & ACI 3\% & ACI 5\% \\
\hline Color & $4.8 \pm 0.4^{2) \mathrm{a} 3)}$ & $4.9 \pm 0.8^{\mathrm{a}}$ & $4.9 \pm 0.5^{\mathrm{a}}$ & $3.6 \pm 0.4^{\mathrm{b}}$ \\
Flavor & $4.3 \pm 0.2^{\mathrm{ab}}$ & $4.6 \pm 0.6^{\mathrm{ab}}$ & $4.9 \pm 0.4^{\mathrm{a}}$ & $4.0 \pm 0.3^{\mathrm{b}}$ \\
Taste & $4.4 \pm 0.3^{\mathrm{b}}$ & $4.8 \pm 0.5^{\mathrm{ab}}$ & $5.1 \pm 0.4^{\mathrm{a}}$ & $3.1 \pm 0.2^{\mathrm{c}}$ \\
Texture & $4.6 \pm 0.5^{\mathrm{a}}$ & $4.6 \pm 0.7^{\mathrm{a}}$ & $4.9 \pm 0.5^{\mathrm{a}}$ & $3.2 \pm 0.7^{\mathrm{b}}$ \\
Overall preference & $4.8 \pm 0.3^{\mathrm{a}}$ & $4.9 \pm 0.4^{\mathrm{a}}$ & $5.2 \pm 0.5^{\mathrm{a}}$ & $3.8 \pm 0.3^{\mathrm{b}}$ \\
\hline
\end{tabular}

${ }^{11} \mathrm{ACI}$, aged black chestnut inner shell. Percentage means the weight \% of total flour weight.

${ }^{2)}$ All values are Mean $\pm \mathrm{SD}(\mathrm{n}=3)$.

3a-b Different superscripts in the same row (aged black chestnut inner shell) are significantly different by Duncan's multiple range test at $p<0.05$.

\section{강도 특성}

숙성 흑율피 첨가에 따른 양갱의 강도에 대한 평과 결과 는 Table 8 과 같다. 윤기는 숙성 흑율피 첨가 $1 \%$ 및 $3 \%$ 군은 4.8점 및 4.6점으로 대조군의 4.9점과 유의적인 차이가 없었으나, 숙성 흑율피 5\%군은 3.3점으로 유의적으로 낮았 다(p<0.05). 이는 기계적 색도 측정 결과(Table 5)에서 명도 (lightness)가 숙성 흑율피 첨가량에 따라 감소한 결과와 유 사하였다.

색은 대조군이 2.8 점, 숙성 흑율피 $1 \%$ 첨가군과 유의적인 차이가 없었으나 첨가량이 증가함에 따라 $3 \%$ 첨가군은 4.9점, $5 \%$ 첨가군은 6.4 점으로 색이 유의적으로 진하게 나 타났다. 숙성 흑율피 향은 흑율피 첨가량이 증가함에 따라 3.8점, 5.4점, 6.6점으로 유의적으로 증가하였다( $\mathrm{p}<0.05)$. 숙 성 흑율피 맛은 숙성 흑율피 $1 \%$ 첨가군은 3.0 점, 숙성 흑율 피 $3 \%$ 첨가군은 5.4점, 숙성 흑율피 $5 \%$ 첨가군은 6.6점으로 흑율피 첨가량이 증가함에 따라 유의적으로 증가하였다 $(\mathrm{p}<0.05)$.

단맛은 대조군이 6.3점으로 가장 높았으며, 숙성 흑율피 첨가량이 $1 \%$ 는 4.6점, 숙성 흑율피 첨가량이 $3 \%$ 및 $5 \%$ 는 동일하게 4.2점으로 대조군에 비하여 낮았다 $(\mathrm{p}<0.05)$. 이는 가용성 고형물 함량 및 환원당 함량이 감소하는 결과(Table 3)와 일치하였다.

경도는 대조군에서 4.5 점이었고, 숙성 흑율피 $1 \%$ 첨가군 은 4.2점으로 유의적인 차이가 없었으나 $3 \%$ 로 첨가량이 증가함에 따라 3.6점으로 유의적으로 낮아졌으며, $5 \%$ 첨가 군은 3.1 점으로 $3 \%$ 첨거군과 유의적인 차이는 나타나지 않았다. 이같은 관능검사 결과는 기계적 조직감 측정 결과
(Table 6)인 경도의 결과에서와 유사한 경향을 나타내었다. 탄력성은 대조군이 4.2점이었고, 숙성 흑율피 첨가량이 $1 \%$ 는 4.1점, 숙성 흑율피 첨가량이 3\%는 3.7점으로 대조군 과 유의적인 차이가 없었으나, 숙성 흑율피 $5 \%$ 첨가군은 3.0 점으로 유의적으로 낮았다( $\mathrm{p}<0.05)$. 기계적 조직감 측정 결과(Table 6)인 탄력성의 결과에서와 유사한 경향을 나타 내었다. 부착성은 대조군이 3.6점이었고, 숙성 흑율피 첨가 량에 따른 유의적인 차이는 없었다. 후미(after taste)의 경우, 대조군에서 1.8 점이었고, 숙성 흑율피 $1 \%$ 첨가군은 3.0 점 으로 유의적인 차이가 없었으나 숙성 흑율피 $3 \%$ 인 경우, 4.6점, 숙성 흑율피 $5 \%$ 인 경우 5.2점으로, 숙성 흑율피 첨가 량이 증가함에 따라 유의적으로 높아졌다.

기호도 검사결과, 전체적 기호도가 가장 높았던 $3 \%$ 숙성 흑율피 첨가 양갱은 윤기, 단맛, 탄력성, 경도가 4.6점, 4.2점, 3.7점, 4.2점이고 색, 율피의 향, 후미, 흑율피의 맛, 부착성 은 4.9점, 5.4점, 4.6점, 5.4점, 3.9점이었다. 전체적 기호도가 가장 낮게 나타난 $5 \%$ 숙성 흑율피 첨가 양갱은 윤기, 단맛, 탄력성, 경도 점수가 가장 낮고 색, 율피의 향, 뒷맛, 흑율피 의 맛, 부착성 점수가 가장 높았다.

Table 8. Sensory properties of Yanggeng added with different amount of aged black chestnut inner shell powder

\begin{tabular}{ccccc}
\hline & Control & ACI $^{1)} 1 \%$ & ACI $3 \%$ & ACI $5 \%$ \\
\hline Glossiness & $4.9 \pm 0.4^{\left.22^{2 a} 3\right)}$ & $4.8 \pm 0.7^{\mathrm{a}}$ & $4.6 \pm 0.4^{\mathrm{a}}$ & $3.3 \pm 0.5^{\mathrm{b}}$ \\
Color & $2.8 \pm 0.8^{\mathrm{c}}$ & $4.2 \pm 0.7^{\mathrm{bc}}$ & $4.9 \pm 0.6^{\mathrm{b}}$ & $6.4 \pm 0.5^{\mathrm{a}}$ \\
Flavor of ACI & $1.0 \pm 0.0^{\mathrm{d}}$ & $3.8 \pm 0.8^{\mathrm{c}}$ & $5.4 \pm 0.6^{\mathrm{b}}$ & $6.6 \pm 0.5^{\mathrm{a}}$ \\
Taste of ACI & $1.2 \pm 0.4^{\mathrm{d}}$ & $3.0 \pm 0.5^{\mathrm{c}}$ & $5.4 \pm 0.5^{\mathrm{b}}$ & $6.6 \pm 0.5^{\mathrm{a}}$ \\
Sweetness & $6.3 \pm 0.5^{\mathrm{a}}$ & $4.6 \pm 0.4^{\mathrm{b}}$ & $4.2 \pm 0.7^{\mathrm{b}}$ & $4.2 \pm 0.3^{\mathrm{b}}$ \\
Hardness & $4.5 \pm 0.6^{\mathrm{a}}$ & $4.2 \pm 0.5^{\mathrm{ab}}$ & $3.6 \pm 0.5^{\mathrm{b}}$ & $3.1 \pm 0.3^{\mathrm{b}}$ \\
Springiness & $4.2 \pm 0.8^{\mathrm{a}}$ & $4.1 \pm 0.4^{\mathrm{a}}$ & $3.7 \pm 0.5^{\mathrm{a}}$ & $3.0 \pm 0.4^{\mathrm{b}}$ \\
Adhesiveness & $3.6 \pm 0.8^{\mathrm{NS} 4)}$ & $3.8 \pm 0.4$ & $3.9 \pm 0.6$ & $4.2 \pm 0.7$ \\
After taste & $1.8 \pm 0.3^{\mathrm{c}}$ & $3.0 \pm 0.7^{\mathrm{b}}$ & $4.6 \pm 0.6^{\mathrm{a}}$ & $5.2 \pm 0.7^{\mathrm{a}}$ \\
\hline
\end{tabular}

${ }^{11} \mathrm{ACI}$, aged black chestnut inner shell. Percentage means the weight \% of total flour weight.

${ }^{2)}$ All values are Mean $t \mathrm{SD}(\mathrm{n}=3)$. Scoring test was conducted (5, very strong; 1 , very weak for astringency and sweet taste; 5 , very like; 1 , very disike for overall preference).

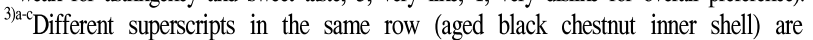
significantly different by Duncan's multiple range test at $p<0.05$.

4) NS , not significant.

\section{요 약}

본 연구에서는 숙성 흑율피 가루를 1, 3 또는 5\% 첨가한 숙성 흑율피 양갱을 제조하여 품질 특성, 관능적 특성 및 항산화 특성을 분석하였다. 숙성 흑율피 양갱의 수분함량 은 $1 \%$ 첨가군은 대조군과 유사하였으나 숙성 흑율피 첨가 량이 증가함에 따라 수분 함량은 증가하였다. 당도와 환원 당은 숙성 흑율피 첨가량이 증가됨에 따라 낮아졌다. $\mathrm{pH}$ 는 
숙성 흑율피 첨가량이 증가함에 따라 감소하였고, 산도는 높아졌다. 명도(lightness)와 황색도(yellowness)는 숙성 흑 율피 첨가량이 증가할수록 낮아졌으며, 적색도(redness)는 높아졌다. 기계적 조직감 측정결과, 경도(hardness)는 대조 군이 높았고, 숙성 흑율피 첨가량이 증가함에 따라 경도는 증가하였다, 응집성(cohesiveness)은 숙성 흑율피 $1 \%$ 첨가 양갱과 $3 \%$ 첨가 양갱은 유의적인 차이를 나타내지 않았지 만, 첨가량이 증가함에 따라 응집성은 감소하였다. 탄력성 (springness)은 숙성 흑율피 첨가량이 증가할수록 낮아졌다. 총 페놀 함량은 숙성 흑율피 첨가량이 증가함에 따라 증가 하였다. DPPH 라디칼 소거능과 hydroxyl 라디칼 소거능은 양갱에 숙성 흑율피 첨가량이 많을수록 $\mathrm{IC}_{50}$ 값이 낮아져 항산화능이 높아졌다. 기호도 검사 결과, 숙성 흑율피 $3 \%$ 첨가군의 전체적인 기호도 점수가 5.2점으로 가장 높은 점 수를 받았다. 이상의 결과로부터 숙성 흑율피를 $3 \%$ 첨가하 여 양갱을 제조할 때 품질 특성, 항산화성 및 관능적 특성이 우수하였으므로, 이를 바탕으로 기능성 식품으로서 개발 가능성이 높을 것으로 사료된다.

\section{감사의 글}

본 결과물은 농림축산식품부의 재원으로 농림수산식품 기술기획평가원의 농생명산업기술개발사업(115098021SB010) 의 지원을 받아 연구되었으며 지원에 감사드립니다.

\section{References}

1. Oh HL, Ahn MH, Kim NY, Song JE, Lee SY, Song MR, Park JY, Kim MR (2012) Quality characteristics and antioxidant activities of Yanggeng with added Rehmanniae radix preparata concentrate. Korean J Food Cookery Sci, 28, 1-8

2. Min SH, Park OJ (2008) Quality characteristics of Yanggeng prepared with different amounts of Astragalus membranaceus powder. J East Asian Soc Dietary Life, $18,9-13$

3. Jeon MR, Kim MH, Son CW, Kim MR (2009) Quality characteristics and antioxidant activity of calcium-added garlic Yanggeng. J Korean Soc Food Sci Nutr, 38, 195-200

4. Park ML, Byun GI (2005) Quality characteristics of pine mushroom Yanggeng prepared by different addition of frozen pine mushroom according to different pretreatment. Korean J Food Culture, 20, 738-743

5. Choi EM, Jung BM (2004) Quality characteristics of
Yanggeng prepared by different ratio of pumpkin. Korean J Food Cookery Sci, 20, 138-143

6. Kim JH, Park JH, Park SD, Kim JK, Kang WW, Moon KD (2002) Effect of addition of various mesh sifted powders from safflower seed on quality characteristic of Yanggeng. Korean J Food Preserv, 9, 309-314

7. Park SH, Cho EJ (1995) Instrumental and sensory characteristics of Yanggeng mixed with kidney bean sediment. Korean J Dietary Culture, 10, 247-253

8. Kwak ES, Kim HR, Lee KJ, Kim MR (2009) Antioxidant activities and quality characteristics of fermented and aged garlic Yanggeng. Korean J Food Cookery Sci, 25, 739-746

9. Joo SY, Choi HY (2012) Antioxidant activity and quality characteristics of cookies with chestnut inner shell. J Korean Food Nutr, 25, 224-232

10. Jeong HR, Kim JH, Jo YN, Jeong JH, Heo HJ (2011) Characterization as cosmetic substances of chestnut inner skin extracts with antioxidant activity. J Agric Life Sci, 45, 183-191

11. Jun DH, Jang YA, Kim HY, Kim SJ, Kim JC, Kim SH, Kweon DJ, Han SI, Lee JT (2013) Inhibitory effects of chestnut inner shell cytokine production from human mast cell line. Kor j Herbology, 28, 55-60

12. Kim MR (2017) Quality Characteristics and Antioxidant Activities of Aged Black Chestnut Inner Shell. J Korean Soc Food Sci Nutr, 46, 343-349

13. Jeon BG, Park CK (2000) A study on the production of chestnut powder in the inner shell (endo carp) of a chestnut from its treatment plant - study on the utilities of separated powder from chestnut inner shell-. J KOWREC, 8, 111-120

14. Choi EJ, Kim SI, Kim SH (2010) Quality characteristics of Yanggeng by the addition of green tea powder. J East Asian Soc Dietary Life, 20, 415-422

15. Han EJ, Kim JM (2011) Quality characteristics of Yanggeng prepared with different amounts of ginger powder. J East Asian Soc Dietary Life, 21, 360-366

16. Han JM, Chung HJ (2013) Quality characteristics of Yanggeng added with blueberry powder. Korean $\mathrm{J}$ food Preserv, 20, 265-271

17. Ku SK, Choi HY (2009) Antioxidant activity and quality characteristics of red ginseng sweet jelly (Yanggeng). Korean J Food Cookery Sci, 25, 219-226

18. Hwang ES, Lee YJ (2013) Quality characteristics and antioxdant activities of Yanggeng with aronia juice. J Korean Soc Food Sci Nutr, 42, 1220-1226 
19. Park EY, Kang SG, Jeong CH, Choi SD, Shim KH (2009) Quality characteristics of Yanggeng added with paprika powder. J Agric Life Sci, 43, 37-43

20. Kim MH, Chae HS (2011) A study of the quality characteristics of Yanggeng supplemented with Codonopsis lanceolata Traut (Benth et Hook). J East Asian Soc Dietary Life, 21, 228-234
21. Seo HM, Lee JH (2013) Physicochemical and antioxidant properties of Yanggeng incorporated with black sesame powder. J Korean Soc Food Sci Nutr, 42, 143-147

22. Oh SH, Kim YW, Kim MA (2004) The antioxidant activities of acetone extracts of chestnut inner shell, pine needle and hop. Korean J Food Culture, 19, 399-406 